\title{
DIREITO DE COOPERAÇÃO ENTRE ESTADOS: A BUSCA DE SOLUÇÕES AOS INTERESSES INTERNOS DA IMIGRAÇÃO
}

\section{ARTIGO ORIGINAL}

CARNEIRO, Dioclécio Salomão ${ }^{1}$

CARNEIRO, Dioclécio Salomão. Direito de cooperação entre Estados: A busca de soluções aos interesses internos da imigração. Revista Científica Multidisciplinar Núcleo do Conhecimento. Ano 05, Ed. 03, Vol. 05, pp. 150-164. Março de 2020. ISSN: 2448-0959, Link de acesso: https://www.nucleodoconhecimento.com.br/lei/cooperacao-entre-estados

\section{RESUMO}

A proposta de pesquisa se baseia em analisar se no instante em que ocorrem as mais diferentes formas de Cooperação entre Estados, a soberania de um ou outro poderá estar em risco, sob o ponto de vista das relações internacionais para com o tratamento independente aos imigrantes. Nesse contexto, busca-se avaliar os pressupostos e consequências desse modelo cooperativo entre os Estados Constitucionais como forma de articulação e condição desse cooperativismo garantindo os direitos ditos fundamentais a essa parcela de indivíduos.

Palavras-chave: Direito Constitucional, democracia, cooperação, imigração, soberania.

\section{INTRODUÇÃO}

Os desafios presentes nos dias atuais estão mais ousados sob o ponto de vista das garantias fundamentais para com aqueles indivíduos que praticam a imigração como forma de busca por melhores condições de vida para si e para seus entes. Contudo,

\footnotetext{
${ }^{1}$ Mestrando em Direito Constitucional, Direitos Fundamentais e Democracia, Bacharel em Direito e Ciências Contábeis.
} 
a história revela diferentes barreiras nesses movimentos, podendo-se citar a Muralha da China, o Muro da Alemanha e, atualmente, o dos Estados Unidos, na fronteira com - México. O debate que levou e leva a construção desses cerceamentos de passagem configura os mais diversos motivos políticos e de suposta segurança que vieram a se intensificar nas fronteiras.

No entanto, o artigo busca retratar a visão além das divisas fronteiriças de cada Estado Nação, concentrando-se na perspectiva do imigrante que se arrisca para viver em ambientes mais seguros, prósperos e de acordo com as suas necessidades pessoais. Movimento esse que sempre ocorreu entre os continentes e que passa a ser estudado no viés das garantias mínimas que o direito internacional poderá arguir a esses indivíduos, com o intento de tornar menos agressiva as políticas internas de cada país para com o atendimento a essas populações que, em muitas das vezes, encontram-se em condições de extrema vulnerabilidade.

\section{O DIREITO COMUM DE COOPERAÇÃO. OS DIREITOS HUMANOS COM STANDARD NORMATIVO INTERNACIONAL VINCULANTE DO ESTADO}

O desafio da Cooperação entre os Estados toma forma a partir da capacidade que cada país tem para com a sua população, seja no âmbito da cultura de aceitação de outras pessoas de diferentes etnias ou mesmo no entrave colocado pela sociedade receptora. No sentido de se ter o preconceito fundido por meio de desculpas dadas pela situação econômica e social ou mesmo pela alegação de trazer consigo esses imigrantes, problemas relacionados a sua conduta, que podem vir a desestabilizar aquela sociedade então organizada e padronizada, são frequentes. Conforme explica Torronteguy (2010), os programas de cooperação estão focados na aplicação, desenvolvimento e conscientização para com os direitos humanos. Entretanto, em muitas das vezes, tem o intuito de contribuir para com as sociedades recebedoras da cooperação, e, assim, é um modelo educação dessas sociedades, visando a garantia dos direitos humanos, não raro, portanto, a ênfase na cultura enviesada do país doador. 
A capacidade e profundidade, como é entendida e interpretada as relações humanas a partir dos seus direitos fundamentais, se dão pela efetiva aplicação dessas garantias, e, dessa forma, no momento em que surge a necessidade dos povos imigrantes em abarcar seus direitos, a relação internacional entre países e o próprio direito internacional atuam como instrumentos mediadores dessas afirmações. Os diferentes países relacionam-se por meio de suas Constituições, cujo ordenamento cria mecanismos que tornam os Estados capazes de atribuir, em seu regimento interno jurídico, qualidades para manter-se independente, mas, ao mesmo tempo, garante a responsabilidade em interagir com as demais nações no intuito de cooperar entre si na busca por soluções urgentes para solucionar os problemas que afligem principalmente as questões humanitárias de suas populações.

Assim, Maliska (2008) reitera que a Constituição Brasileira, em suas relações internacionais, rege-se por princípios que prezam pela prevalência de sua soberania aos direitos humanos, além da solução pacífica dos conflitos, cooperação entre povos para o progresso da humanidade e pela integração entre países latinoamericanos. Buscando-se a interpretação mais adequada ao objetivo final da norma, nesse caso, atribui-se total coerência e concomitância para com o respeito aos fundamentos que regem a dignidade da pessoa humana, seja ela imigrante ou não. Para isso, cabe ressaltar a importância da interação permanente entre os Estados internacionais como modelo de prática formal e concreta nas ações para proteção daqueles que se encontram em situações degradantes e de vulnerabilidade, aqui, no caso, os imigrantes que possuem a condição de refugiados.

O Brasil exerce um papel importante na participação internacional, pois é um país de ideais pacíficos e que preza pelo diálogo na resolução dos conflitos. Traz, assim, um modelo de cooperação alinhado com a paz entre as nações e seus povos. Esse, portanto, é o modelo apresentado nos debates internacionais. Para Cintra (2010), a Cooperação Brasileira para o Desenvolvimento Internacional tem sido movida por princípios alinhados às visões de relações equânimes e de justiça social, constituindose como um importante instrumento de política externa. Nesse contexto, elevar as questões relacionadas aos direitos humanos em meio aos debates faz com que esse 
assunto seja relevante nos encontros internacionais, pois é o momento oportuno para se buscar por melhores condições de vida para a população local e imigrante. É um ideal que a nação brasileira se apoia.

O Brasil, a partir de suas lideranças políticas e jurídicas e, também, a população civil organizada, tem percebido a necessidade de cada vez mais estar presente nas discussões internacionais sobre a movimentação de pessoas entre as diversas nações do globo. Ao redigir sobre a preocupação do Estado brasileiro, Araujo (2008) frisa que a cooperação jurídica internacional tem aumentado, porque, a cada dia, cresce o contingente de brasileiros que estão no exterior, os novos contornos da inserção internacional do país e o combate ao crime de caráter transnacional. É uma questão de necessidade ao Estado brasileiro assumir posições de diálogo e pacificar questões controversas como forma até de garantir a segurança de seus cidadãos que estão temporariamente ou por tempo indeterminado em terras estrangeiras.

O movimento de imigração surge em grande escala a partir de fatores que impulsionam sua ocorrência, seja devido aos problemas relacionados a violência, miséria, guerras, condições climáticas e até mesmo em razão de fatores naturais como terremotos, alagamentos, tornados, dentre outras situações atribuídas à natureza. Informa Piovesan (2006) que as questões econômicas e as próprias guerras são os principais motivadores das imigrações entre países. Essa concepção, portanto, reitera consequências do movimento recente na história, conhecido como pós-guerra, cuja resposta se dá devido as atrocidades e horrores vividos e cometidos durante o nazismo. Essas condições forçam os indivíduos à moverem-se de um lugar para outro, deixar suas raízes, histórias e familiares por motivos diversos de extrema urgência e necessidade na maioria dos casos.

Portanto, há que se desenvolver e concretizar os direitos humanos de forma incessante no caminho da evolução do direito internacional, considerando as legislações domésticas de cada nação receptora. Todo processo de evolução, seja ele voltado para as condições jurídicas, econômicas e sociais sofre e necessita de ajustes perenes para que se acompanhe as necessidades e fatos que venham a ocorrer no tocante ao movimento de pessoas em todo o mundo. Na leitura de Gomes 
(2011), o processo de globalização ao passo que propicia a internacionalização do sistema produtivo e serviços, evidencia, também, desejos, diga-se imediatos, para solucionar as necessidades de sobrevivência da humanidade que são "pano de fundo" social para uma realidade concreta do poder de mudança.

Com o movimento da globalização que se instaurou a partir de práticas de circulação do capital nas mais diferentes nações, seja por meio dos investimentos, lucro realizado, contratação de mão de obra e demais insumos necessários para a atividade econômica, o viés desse movimento foi pautado, principalmente, na massificação do consumo de produtos e a custos cada vez menores, o que não é ruim para os indivíduos do globo, pois tende a facilitar o acesso de todos aos produtos e serviços necessários. Esse movimento de capital entre os países, denominado globalização, também gera fatores que culminam na prática da imigração em busca por melhores condições de vida e concretude dos direitos fundamentais, pois onde há o capital circulante, trabalho e renda, o fluxo de pessoas tende a direcionar-se por uma questão óbvia de conquista as melhores condições de sobrevivência para si e seus próximos.

O direito internacional juntamente com as Organizações Internacionais busca, em grande medida, deslumbrar políticas de proteção aos imigrantes e, principalmente, concretizar, de fato, os direitos fundamentais a esse grupo de veras vulnerável em países de precária condição e segurança jurídica, mesmo que os direitos dos estrangeiros sejam mínimos. Contudo, ao lado do sistema normativo global, surgem os sistemas regionais de proteção que buscam internacionalizar os direitos humanos nos planos regionais, particularmente na Europa, América e África, conforme Piovesan (2009). Nesse contexto, prezar por uma regionalização para além das fronteiras continentais não deixa de ser mais uma tentativa de colocar em prática os fatores e garantias, mesmo que mínimos, aos refugiados, imigrantes e ao turista, devido à sua vulnerabilidade. 


\section{OS FLUXOS MIGRATÓRIOS ATUAIS. ANÁLISE DOS CASOS EUROPEU E BRASILEIRO}

É inegável a movimentação do capital nas diferentes nações, atuando em nome da chamada globalização, na busca pelo lucro, redução de custos e produção de massa dos produtos. Assim, é possível observar, claramente, que o cenário econômico contribui largamente para o favorecimento ou não das imigrações e movimentações da população humana. Sobre o cenário brasileiro, Lisboa (2004) apresenta uma espécie de reconstituição das bases econômicas e da força de trabalho e da mobilidade do capital internacional, colocando-se com articulador da distribuição das populações no território. Nesse contexto, a rotatividade de capital mundo adentro e o impulsionamento do trânsito da mão de obra, tendo ou não qualificação, a custo baixo, alimentam, assim, as atividades produtivas espalhadas no globo, de modo a assegurar a sua reprodução e transformação com o fim de atender demandas.

No contexto social, a economia representa um papel de relevante importância, a ponto de dirimir pessoas de diversos locais do globo em busca de condições melhores de vida para si e para sua família. Ademais, o encargo dessa movimentação precisa, também, ser levado em consideração nas políticas aplicadas entre nações, e, ainda, na atuação interna de cada país frente aos desafios de acomodar e reduzir as desigualdades existentes internamente cujas pessoas, pela sua própria consciência e conhecimento, tomam a decisão por avançar ao estrangeiro com o intuito de prosperar frente as dificuldades vivenciadas em sua terra natal. Os processos migratórios não devem ser tratados como uma anomalia de forma genérica irrestrita de análise, haja visto esse processo existir desde os primórdios da civilização humana.

Nessa perspectiva, é possível analisar que o ser humano sempre esteve em busca de melhores condições de vida e, também, o espírito desbravador esteve sempre ao lado da necessidade de se descobrir novas áreas territoriais das quais pudessem ser exploradas e colonizadas. Elhaji (2012) declara que a condição fundadora da espécie humana fez com que todos os cantos do planeta fossem colonizados, e, assim, não se pode encarar a migração como anomalia ou exceção, pois é ela quem sustentou o 
processo de humanização, construção de bases materiais, capacidade de abstração e, ainda, reformulou o significado social e histórico do sujeito. No entanto, há que se declarar que, em muitas situações, há a necessidade da imigração com o intento de fuga imediata por ocorrências básicas humanas, como, por exemplo, a fome e a violência nos diversos espaços geográficos espalhados ao redor do planeta.

Toda análise que remonta as pesquisas sobre o Direto Internacional dos imigrantes, precisa, necessariamente, considerar o estrangeiro imigrante em sua plenitude a partir de ações propostas como instrumentos de efetivação dos direitos fundamentais da pessoa humana, na condição de pessoa inegavelmente vulnerável frente ao Estado estrangeiro. É nesse viés de proteção que o direito, juntamente com os órgãos responsáveis pela articulação de projetos e políticas que possam ser efetivas na sustentação das medidas cabíveis, devem garantir o mínimo assegurado pelo direito, como, por exemplo, o de retornar para sua nação em companhia de seus entes familiares. Contudo, Zamberlam (2004) destaca que há em comum para os deslocamentos humanos fatores como: conflitos bélicos, precárias condições de vida, lutas políticas, étnicas, sociais e religiosas, além das catástrofes naturais e provocadas, desigualdades sociais e, também, a própria realização pessoal.

Nenhum movimento populacional, seja em caráter definitivo ou, até mesmo, temporário, pode ser acreditado como sem motivo real ou de necessidade, e, dessa forma, fica evidente que os fatores que levam a grande maioria das pessoas a se deslocar de seus países de origem para outros estão diretamente relacionados com problemas devido às más ou péssimas condições de sobrevivência, seja pela falta de oportunidades ou mesmo por desacreditarem que dias melhores virão. Visam amenizar o sofrimento ou mesmo a miséria de comida, água, falta de organização estatal, corrupção, desigualdade extrema etc. Assim, um Estado que se quer tem condições para respeitar seus cidadãos a partir da idoneidade com o dinheiro público, que não investe de forma eficiente e que cause não preza pela coletividade faz com que a população deseje viver em um local melhor.

Conforme pesquisa realizada, é possível assegurar que a globalização da economia mundial é um dos fatores de maior relevância na tomada de decisões por parte dos 
indivíduos que assim decidem por realizar o movimento migratório as mais diferentes nações. O destaque que Martine (2005) faz é no sentido de reiterar, em seu estudo, que a globalização aumenta o fluxo de informações a respeito de oportunidades ou mesmo de padrões de vida. Dessa forma, esses fatores evidenciam que a vontade em migrar e aproveitar certas comodidades que aparentam existir são criadas em outros países, o que impulsiona esses sujeitos. Em suma, os padrões de migração internacional se refletem na desigualdade e nas mudanças econômicas e sociais entre as nações, ratificando, então, a globalização como fator preponderante aos movimentos migratórios.

A busca em gerar lucro e riquezas a partir de investimento é convertida em trabalho àqueles que necessitam e é uma necessidade do próprio ciclo produtivo. Contudo, a mão de obra, por consequência, une o útil ao transformar em agradável para aqueles que encontram na imigração uma forma de sanar suas necessidades pessoais e coletivas, uma vez que o Estado de sua origem não teve a capacidade de propiciar a auto geração do recurso da melhor forma possível a ponto de garantir que seus cidadãos não tivessem o interesse genuíno aliado a perspicaz suficiente em galgar novos horizontes de concretude no exterior. Tratando-se da segurança jurídica, é necessária para que os indivíduos possam, mesmo que minimamente, ter a segurança necessária de que o país receptor Ihes conferirá o direito básico de retornar as suas origens. Dessa forma, torna-se necessária a discussão, de modo que essa premissa de fato seja instaurada no direito internacional e alcance a normativa jurídica interna de cada Estado.

A precariedade, por sua vez, está diretamente relacionada com o nível de desenvolvimento de cada nação, e, assim, não se considera, apenas, o aspecto econômico, mas também a interpretação e aplicação do próprio direito, e, dessa forma, parte-se do entendimento de que a imigração é um processo natural, conforme fatores anteriormente já citados. Então, faz-se urgente a aplicação do ordenamento jurídico, de forma a garantir o mínimo necessário das garantias fundamentais do ser humano. Portanto, diz-se que os direitos de emigrar e de imigrar são, pois, dependentes de regulamentação legal e devem possuir, em seu bojo, uma 
fundamentação capaz de lhes conferir legitimidade, suportados em postulados internacionais de direitos humanos e nos princípios constitucionais que regem a ordem jurídica interna, conforme narra Santos (2014).

O esforço necessário de cada país receptor, além do apoio em organismos internacionais capazes de influenciar políticas adequadas, é necessário para que haja a garantia dos direitos fundamentais em suas normas jurídicas, o que se pode entender como direito à vida, abrigo, saúde, alimentação, união entre os membros da mesma família e o próprio transporte de retorno, se assim for o regramento e desejo do país receptor. As questões básicas da política de imigração devem ser sensíveis ao tratamento diferenciado, e, dessa forma, o imigrante-indivíduo passa para a condição adequada de refugiado na busca de preservar sua vida e seus familiares no instante de desespero frente aos fatos vividos no seu local de origem. É objeto de estudo, também, os locais cujo imigrante irá frequentar, haja visto que ele não está limitado somente no espaço de trabalho buscado em um primeiro momento. Deve-se contemplar, também, os demais espaços necessários para a convivência junto aos demais nativos daquela comunidade ao qual se encontra.

Para tanto, Martins Junior e Dias (2013), destaca que as pesquisas acadêmicas apontam para a reflexão não só do imigrante centrado no espaço que ocupa, mas também para a transformação gerada na sociedade receptora. $O$ fato de frequentar lugares como clubes, jogos de futebol, locais religiosos ou outros espaços de convivência social influencia o estilo de vida, além dos objetivos iniciais, reformulados ou não. A adequação do direito interno e externo dos indivíduos imigrantes versus a sociedade receptora, com o intuito de minimizar ou mesmo neutralizar ações de hostilidade para com esses indivíduos, necessitam, pelas características já demonstradas, de segurança estatal. Essa mobilidade é oriunda das próprias mazelas em que a sociedade antiga e atual insistem em carregar consigo, em razão de guerras, autoritarismo, injustiça, indiferença e, principalmente, devido à intolerância. São fatores que causam profundos choques desnecessários ao convívio humano.

O controle realizado por cada Estado com o intuito de reduzir esse fluxo migratório, ao mesmo tempo que busca proteger sua população interna, também gera conflitos 
do ponto de vista das garantias fundamentais do ser humano, ao passo que os interesses locais acabam sendo colocados em cheque no instante que os processos migratórios se tornam cada vez maiores e impulsionados por objetivos similares de cada indivíduo, ou seja, busca por melhores condições de vida. Revela Pires (2002) que a eficácia das políticas de imigração que visam regular os atuais fluxos dependem, necessariamente, da capacidade do Estado de atuar para mobilizar os fatores de crescimento desses movimentos.

Cita-se, portanto, considerando o contexto apresentado, que o mercado de trabalho, somado ao alargamento dos direitos dos estrangeiros, devem ser igualmente analisados. Políticas centradas em dispositivos de limitação de entrada no país destinatário apenas apresentarão resultados à longo prazo, pois dependem do desenvolvimento da colaboração internacional no controle das fronteiras. Destaca-se, aqui, que a entrada de populações em outros Estados e a sua conveniência está, também, atrelada à necessidade de o país receptor dispor de mão de obra ou mesmo melhorar o déficit de reposição populacional, o que tem ocorrido com frequência em alguns países da Europa.

\section{IMPLICAÇÕES INTERNAS DA IMIGRAÇÃO. O ESTADO RECEPTOR E A RESPONSABILIDADE INTERNACIONAL}

É compreensível, em certa medida, que pessoas do Estado receptor tenham reações negativas para com a população de imigrantes, pois são tomadas pela confusão dos direitos que deveriam ser assegurados pelo Estado nação, entretanto, ela não os garante, ficando, assim, um vácuo na memória de direitos que não usufruem, por vezes e repetidamente, pela falta de responsabilidade na gestão do gasto público, causando, assim, problemas reais de relutância em aceitar, mesmo que de forma temporária, pessoas oriundas de processos migratórios. Dessa forma, persiste, ainda, no Brasil, uma tendência que considera a nacionalidade e a cidadania como sinônimos, o que não se traduz numa verdade. Enquanto o primeiro possui forte ligação com o Estado, o segundo comporta qualidades do indivíduo, no entendimento de Cleto (2015). 
Entende-se, contudo, não só a capacidade cultural em aceitar, de forma pacífica e ordeira, a entrada daqueles que buscam melhores condições de vida, mas também a organização jurídica, estatal, política e econômica somadas ao modelo interpretativo de aceitação ou negação de populações estrangeiras à sociedade receptora envolvem esse processo. A forma como acontecem as imigrações pode ser classificada devido ao alto risco de vida, como em casos de guerras ou devido à própria intolerância religiosa, mas também compreende-se fatores, como, por exemplo, as situações de busca por trabalho, melhores remunerações ou em razão de quererem viver em um país com fatores favoráveis à vida, sobretudo no âmbito cultural, da estabilidade jurídica e financeira, ou, até mesmo, pelo fato de que investidores veem melhores condições de aplicação de recursos financeiros nessa região.

E, nesse patamar, Sá e Fernandes (2016) aponta para a relevância de verificar que os imigrantes do Brasil, que se dirigem para Portugal, planejam esse processo, diferentemente de imigrantes que compõe outros fluxos para a União Europeia, a exemplo sírios e líbios. Há que se ressaltar os fatores explícitos para esses, como a expulsão imposta pela situação política e religiosa antidemocrática. O oposto, imigrantes da língua portuguesa tendem a migrar por canais mais seguros, a rigor aeroportos. Pode-se afirmar, contudo, que o caminho da legalidade e pelos meios convencionais de acesso ao país estrangeiro determinam a maior segurança e propiciam melhores condições de se alcançar o objetivo pelo qual lançou-se no movimento de migração, pois as condições de entrada por meios ilegais e arriscados tendem, em sua grande maioria, ser sofridas.

Para isso, se faz necessário, cada vez mais, assegurar as garantias mínimas concretas e internacionais para que possam causar uma espécie de pressão interna ao país receptor como mecanismo de permitir, aos imigrantes, condições para que se instalem, ou, em caso negativo, para que possam, ao menos, ter seu direito de retorno ou refúgio, se assim a situação original sugerir. A ocorrência do trabalho informal, em muitas das vezes, ultrapassa a barreira da atividade executada de forma digna, pois se emprega a mão de obra barata e, em muitas vezes, desqualificada, sobretudo em países pouco desenvolvidos ou com cultura impregnada de exploração abusiva para 
com o próximo. Soma-se esses fatores à condição de imigrante, pois, em muitos dos casos, a sua permanência é ilegal, e, assim, aceita qualquer atividade de exploração, pois é o único meio encontrado para permanecer naquele país ou voltar para seu país de origem, o que, para essas pessoas, é pior do que as suas condições atuais.

Assim, submete-se à estas condições com esperança de melhorar sua condição frente as oportunidades que vierem a ocorrer. Agarram-se na possibilidade de ascender profissionalmente, sobretudo aqueles que possuem o domínio da língua estrangeira e qualificação aceita no local receptor. Entretanto, dependem, também, da condição econômica e jurídica dessa nação para possibilitar a concretude do desejo daquele que imigra. Para Reynolds (1980), imigrantes e grupos minoritários geralmente executam o papel mais árduo no processo de inovação, além da força de trabalho mais servil. A alternativa para essa transformação seria descentralizar a produção para os parceiros de comércio menos ricos. $E$, também, à medida em que a capacidade empresarial vigorosa se torna menos acessível em países desenvolvidos, espera-se que haja a declinação para investimentos no estrangeiro e que os produtos e serviços se tornem cada vez mais competitivos.

É necessário, também, destacar os custos do Estado em aceitar e manter as populações imigrantes, pois são fatores que acarretam o efeito direto ou indireto nas contas públicas e, consequentemente, em valores a mais para serem desembolsados pelo contribuinte. Haja visto, é necessário garantir àqueles que advém de outras nações, as mesmas condições de saúde, educação, trabalho e moradia, sob pena de encaminhá-los ao país de origem do qual, em muitas das vezes, por condições humanitárias, não é possível. Ou assumir de fato a situação que se encontra e desenvolver, dentro do possível, ações para esses sujeitos. A grande maioria dos países tiveram a sua formação baseada em indivíduos que assumiram o risco de imigrar em busca de melhores oportunidades de vida, ajudando, assim, a construir muito do que tem presente nas cidades espalhadas pelos continentes.

As populações de imigrantes, por se originarem de diversas regiões do globo, criaram costumes diversos e a própria condição de saúde pré-existente se torna um desafio para os países receptores. Haja visto, poderem necessitar de contribuições médicas 
diferenciadas daquelas ofertadas pelo seu Estado de origem. Esse é um exemplo específico de grupos de imigrantes que se fixam em outros lugares. Relata Martes e Faleiros (2013) que o Estado que reconhece o direito universal à saúde e estabelece, em sua Constituição, não significa, porém, que o executam ou que o fazem de forma efetiva. No entanto, para os imigrantes que possuem características distintas da população nativa, deve-se elaborar e implementar meios de garantir o acesso dessa população à saúde.

Somente com tratamento específico se torna possível tratar os indivíduos vulneráveis, principalmente aqueles que se encontram em condição de refugiados. Assim, o modelo político e normativo é um instrumento eficaz para garantir a inserção desses que buscam firmar residência no estrangeiro. É claro que o texto elenca principalmente aqueles que se encontram em situação de vulnerabilidade indiscutível, pois há outros casos que a imigração se faz pelas vias ditas seguras, em conformidade com o direito público interno de cada país e sequer, em alguma medida, necessitará de toda proteção advinda do aparato Estatal. É possível determinar, com grande margem de acerto, que existem países que expõem esses imigrantes à uma dura jornada, pelo fato de esses terem se deslocado de seu país natal para o estrangeiro. Entende-se que é uma forma de se garantir o bem-estar.

A América Latina contribui, de modo significativo, com a inserção desses indivíduos no exterior. Ao se realizar uma análise dos fatores que levam a essa prática, percebese a prevalência de alguns fatores como, por exemplo, a corrupção, violência, falta de trabalho ou remuneração muito baixa, além da desigualdade absurda que gera um verdadeiro abismo entre ricos e pobres. Isso, sem dúvida, demonstra a realidade de um país "baronil", como é o caso da nação brasileira. Na leitura de Patarra (2005), nos países da América do Sul, assistiu-se, de modo geral, um processo de democratização marcado por crises financeiras, déficit fiscal, dívidas externas e internas crescentes e o estancamento do processo produtivo, imprimindo, assim, como contrapartida, o aumento da pobreza, da desigualdade e exclusão, cujo resultado é o distanciamento cada vez maior dos países ricos. 
A simples democratização sem a verdadeira e concreta cidadania gera descontentamento da população e os menos favorecidos se veem com duas opções de escolha: seja a aceitação e isso não necessariamente significa adotar o silêncio ou a busca por terras estrangeiras. Sua perspectiva de pleitear novos horizontes de conforto e segurança pessoal, social e jurídica, nos moldes de países desenvolvidos e amadurecidos, acarreta a busca por melhores soluções. Pode-se dizer que a visão de um Estado fechado politicamente e fisicamente a partir de grades, telas ou muros que impedem a circulação de pessoas é uma medida um tanto quanto retrógrada e opressora para com a humanidade. A visão global de economia não permite mais a ideia de isolamento, pois as nações se engrandecem ao discursar de suas economias caseiras e liberais, no entanto, fecham-se para a humanidade, aí pode-se caracterizar uma verdadeira exploração do ser humano em sua essência.

Países que se blindam fisicamente não podem estar no mercado internacional, pois explorarão, de forma pura, o lucro e a economia global sem o retorno humanitário com os países com os quais comercializam. Isso poderia estar em discussão na alta cúpula da Organização Mundial do Comércio, pois em todo lucro gerado há o retorno para a sociedade, da qual se obtém ganhos financeiros. De acordo com essa visão, a soberania estatal, que era absoluta e unitária na visão vestfaliana, desagregou-se devido aos processos de globalização e de multiculturalismo conforme destaca Bernardes (2011). Nesse viés, tudo passa a ser globalizado, devido à ênfase econômica nas relações comerciais liberais. Em contrapartida, mescla-se o livre comércio entre as nações, mas também há o desafio de sanar as dificuldades por elas passadas. No empenho de equilibrar o capital financeiro que circula de um local para o outro do globo, esses efeitos e consequências que são previsíveis devem ser intermediados e sanados no espaço público do debate,

Alinhando-se o interesse público com o privado, cria-se, assim, um ponto de equilíbrio nas relações comerciais, sem que gere, portanto, tamanha desvantagem para uma das partes. Talvez a única opção seja a sua população interna migrar em busca do capital monetário circulante, onde quer que esteja. Esse, portanto, é o preço que se paga quando se depara com desigualdades profundas nas relações comerciais, cujo 
lucro não gera riqueza às gerações, mas apenas a concentração cada vez maior e individualizada, fruto da mais valia da mão de obra e da exploração dos recursos naturais. A forma como se interpreta o fenômeno da imigração está diretamente relacionada com a capacidade de um Estado amparado em seus valores, práticas políticas e jurídicas, e, assim, sugere-se o quanto se pode alcançar na garantia dos direitos de seus cidadãos, e, também, daqueles que buscam alguma forma de proteção e construção de suas vidas diferente daquela ofertada pelo seu Estado de origem.

\section{CONSIDERAÇÕES FINAIS}

Cabe destacar que os direitos humanos universais, como bem retrata Botelho (2005), compreendem o direito à vida, à não submissão ao tratamento desumano ou degradante, não ser submetido à escravidão, proteção em relação ao arbitrário, direito à segurança e igualdade, a ter uma existência decente e livre da fome e a liberdade de expressão. São, portanto, premissas que exercem papel de sustentação de qualquer sistema jurídico democrático, do qual o Estado tem, por obrigação, assegurar tal alicerce destacado, sob pena de provocar a ruína social.

O movimento populacional, por ser tratado como algo que ocorre com certa naturalidade, de acordo com a própria história internacional retratada, reitera, então, que se prezar pelas garantias fundamentais, e, quando não concretizadas, podem acarretar barbáries contra os indivíduos que são os mais vulneráveis frente ao poder militar, de guerrilhas, religioso e alvos de intolerância, fatores esses que os colocam em situações de desigualdade. Historicamente, os imigrantes sempre foram explorados e é uma realidade ainda presente, e, dessa forma, precisa ser combatida.

\section{REFERÊNCIAS}

ARAUJO, N. de. A importância da Cooperação Jurídica Internacional para a atuação do Estado Brasileiro no plano interno e internacional. Manual de cooperação jurídica internacional e recuperação de ativos, p. 39, 2008. 
BERNARDES, M. N. Sistema Interamericano de Direitos Humanos como esfera pública transnacional: aspectos jurídicos e políticos da implementação de decisões internacionais. SUR, v. 8, n. 15, p. 135-156, 2011.

BOTELHO, T. Direitos humanos sob a ótica da responsabilidade internacional. Revista da Faculdade de Direito de Campos, Ano VI, n. 6, p. 601-652, 2005.

CINTRA, M. A. M. Cooperação brasileira para o desenvolvimento internacional: 2005-2009. Brasília: IPEA, 2010.

CLETO, J. Implicações do direito ao voto aos imigrantes: ameaça à soberania nacional ou efetivação de um direito fundamental? Revista Brasileira de Políticas Públicas, v. 5, n. 3, 2015.

ELHAJJI, M. Mapas subjetivos de um mundo em movimento: Migrações, mídia étnica e identidades transnacionais. Revista Eptic, v. 13, n. 2, 2012.

GOMES, D. G. P. Os direitos sociais no âmbito do sistema internacional de normas de proteção dos direitos humanos e seu impacto no direito brasileiro: problemas e perspectivas. Os direitos sociais no âmbito do sistema internacional de normas de proteção dos direitos humanos e seu impacto no direito brasileiro: problemas e perspectivas. 2011. Disponível em: https://juslaboris.tst.jus.br/bitstream/handle/20.500.12178/97621/2011_gomes_dinau ra_direitos_sociais.pdf?sequence=1\&isAllowed=y. Acesso em: 08 mar. 2020.

LISBOA, W. T. Cenas da diversidade no ambiente empresarial: os atuais fluxos migratórios internacionais ao Brasil e o desafio da interculturalidade. Organicom, v. 11, n. 21, p. 177-186, 2014.

MALISKA, M. A. Constituição e cooperação normativa no plano internacional: reflexões sobre o voto do Ministro Gilmar Mendes no Recurso Extraordinário n. 466.343-1. Espaço Jurídico Journal of Law [EJJL], v. 9, n. 2, p. 113-124, 2008. 
MARTES, A. C. B; FALEIROS, S. M. Acesso dos imigrantes bolivianos aos serviços públicos de saúde na cidade de São Paulo. Saúde e Sociedade, v. 22, p. 351-364, 2013.

MARTINE, G. A globalização inacabada: migrações internacionais e pobreza no século 21. São Paulo em perspectiva, v. 19, n. 3, p. 3-22, 2005.

MARTINS JUNIOR, A; DIAS, G. Imigração brasileira contemporânea: discursos e práticas de imigrantes brasileiros em Londres. Análise Social, n. 209, p. 810-832, 2013.

PATARRA, N. L. Migrações internacionais de e para o Brasil contemporâneo: volumes, fluxos, significados e políticas. São Paulo em perspectiva, v. 19, n. 3, p. 23-33, 2005.

PIOVESAN, F. Direitos humanos: desafios da ordem internacional contemporânea. Direitos humanos, v. 1, p. 15-37, 2006.

PIOVESAN, F. Direitos sociais: proteção nos sistemas internacional e regional interamericano. Revista Internacional de Direito e Cidadania, n. 5, p. 67-80, 2009.

PIRES, R. P. Mudanças na imigração: uma análise das estatísticas sobre a população estrangeira em Portugal, 1998-2001. Sociologia, Problemas e Práticas, n. 39, p. 151-166, 2002.

REYNOLDS, C. W. Algumas implicações do intercâmbio global entre países ricos e pobres: o exemplo dos EUA. Revista de Administração de Empresas, v. 20, n. 2, p. 35-41, 1980.

SANTOS, C. G. B. dos. A criminalização da imigração irregular e os direitos humanos: os casos específicos de Brasil e Itália. Revista UNI-RN, v. 9, n. 1/2, p. 101, 2014.

SÁ, P. R. C; FERNANDES, D. M. Além do portão de desembarque: uma análise da conectividade dos aeroportos portugueses e suas implicações sobre os fluxos 
migratórios/Beyond the boarding gate: an analysis of the Portuguese airports and their implications on migration flows. Caderno de Geografia, v. 26, n. 1, p. 77-97, 2016

TORRONTEGUY, M. A. A. O papel da cooperação internacional para a efetivação de direitos humanos: o Brasil, os Países Africanos de Língua Oficial Portuguesa e o direito à saúde. Revista Eletrônica de Comunicação, Informação e Inovação em saúde, v. 4, n. 1, 2010.

ZAMBERLAM, J. O processo migratório no Brasil e os desafios da mobilidade humana na globalização. Porto Alegre: Pallotti, 2004.

Enviado: Setembro, 2019.

Aprovado: Março, 2020. 